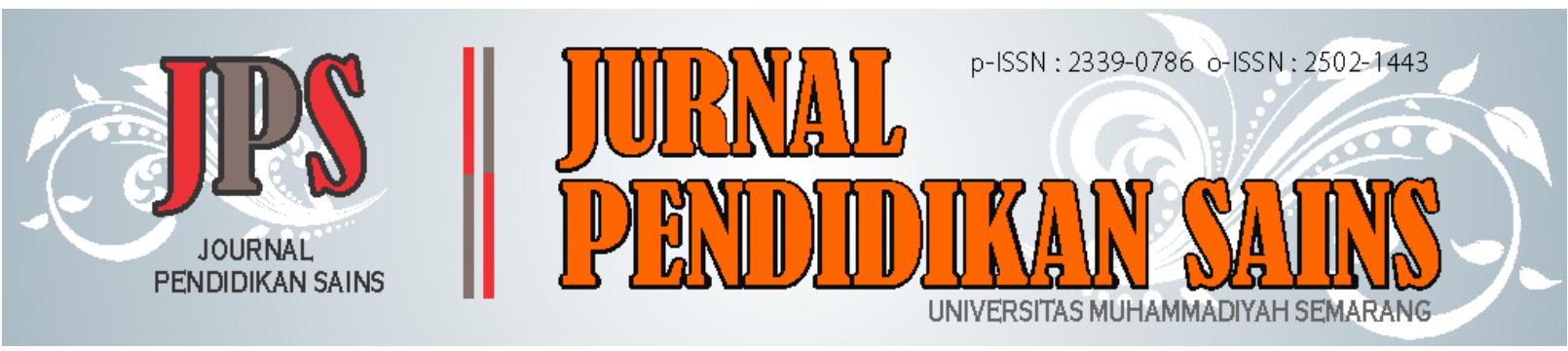

\title{
Development of Animated Media-based Discovery Learning to Improve Scientific Literacy Content for Senior High School Students in Human Circulatory System Material
}

\author{
Andika Widiyana $^{\mathrm{a}, 1}$, Risya Pramana Situmorang ${ }^{\mathrm{b}, 2, *}$, Marisa Christina Tapilouw ${ }^{\mathrm{c}, 3}$ \\ a,b, Biology Education Study Program, Faculty of Biology, Universitas Kristen Satya Wacana, Salatiga, Indonesia \\ ${ }^{1}$ andika.widiyana321@ gmail.com; ${ }^{2}$ risya.situmorang@uksw.edu*; ${ }^{3}$ marisa.tapilouw@uksw.edu \\ * corresponding author
}

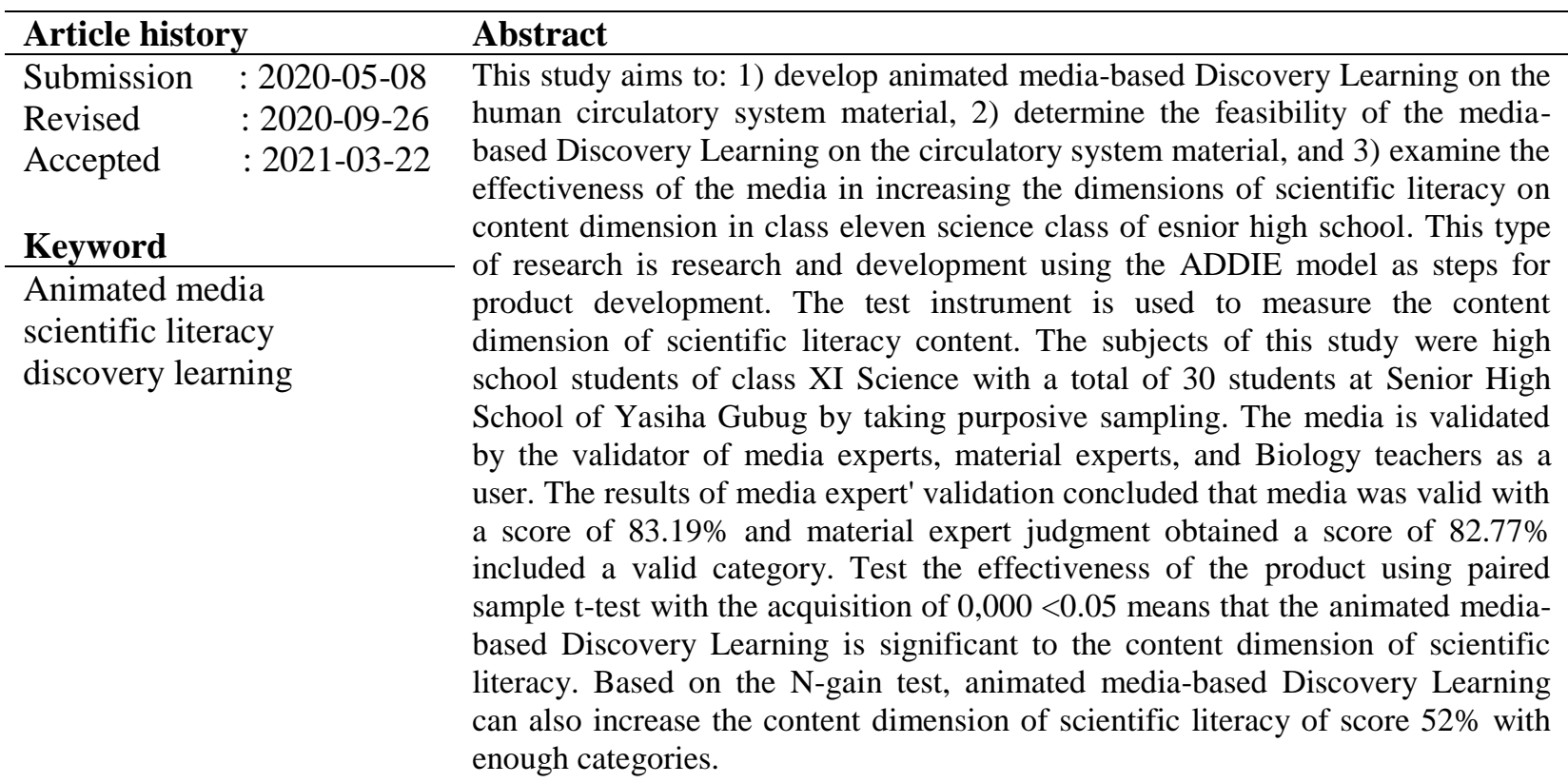

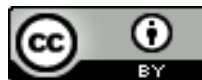

This work is licensed under a Creative Commons Attribution 4.0 International License (C2021 Jurnal Pendidikan Sains Universitas Muhammadiyah Semarang

\section{INTRODUCTION}

The development of globalization supported by technological, it has become a reality in the 21 st century since that condition has penetrated all fields including education. This fact needs to be addressed with the initiation and anticipation in facing global challenges. Rapid global change can also affect every educator, including science teachers in Indonesia. We have to be able to construct the teaching process creatively and innovatively to improve students' competence. Therefore, the management of learning in Indonesia, especially in the field of science, needs to be taken seriously to empower students' abilities as holistic (Arfiyanto \& Pusporini, 2017).

The ability of students who are empowered in the field of science is scientific literacy. This is since the acquisition of scientific literacy of Indonesian students in the last ten years has shown low 
achievement. According to PISA in 2015 and 2018, Indonesian students' scientific literacy is still at level three with a low category (OECD, 2019). Based on this achievement, Indonesia only ranks 70 out of 78 participating countries, or in other words, was in the second-lowest rank of all PISA participating countries (Tohir, 2019). This problem should be a serious concern for teachers who have been teaching monotonous material presentation and often neglect students to process their knowledge through direct learning experiences.

Rusniati (2016) explained that one of the aspects that had caused the low achievement of scientific literacy in Indonesia is the teaching process. It was still dominant in the textual process. Learning still did not lead to the process of forming knowledge based on scientific decision-making. Scientific decision-making is closely related to scientific literacy because scientific literacy is the ability to know and understand a concept as a basis for consideration in drawing conclusions and making decisions regarding natural phenomena and human activities. (Arohman dkk., 2016). An understanding of the main concepts in science is needed to understand natural phenomena including human activities. This means that the dimension of scientific literacy content is included natural phenomena. The dimension of scientific literacy content became the basis for science learning since it is the key to building knowledge (Nofiana \& Julianto, 2018). Building scientific literacy content requires a learning media which can facilitate student to identify information. The use of learning media is carried out so that the new knowledge obtained by students and can shape students' cognitive processes, especially science literacy content (Ahluwalia, 2016; Asyhari, 2015; Nurhayati, 2018).

One of the software which can be designed interactive and facilitate students to develop scientific literacy dimensions is Adobe Flash. Adobe Flash can be used to design animation media in the form of presenting text, sound, and images simultaneously (Suprapto, 2006). Adobe Flash also provides an attractive visualization so that it can be easier for students to understand concepts. Besides, adobe flash can also be designed to create interactions to stimulate students' scientific skills through questioning activities, conveying ideas, and drawing scientific conclusions. Presentation of material on animation media requires scientific learning steps to facilitate students in improving the ability of the dimensions of scientific literacy content. One of the scientific learning models that can be used is the Discovery Learning model.

Discovery Learning is a problem-solving model that invites students to understand concepts through direct activities (Ilahi, 2012). The problem presented is a scientific phenomenon that is contextual and can be linked to scientific problem-solving activities. The Discovery Learning learning model consists of several phases, namely, stimulation or stimulation, problem identification, data collection, data processing, verification or proof, concluding (Sudarmin, 2015). In their research, Dewi et al., (2017) found that Discovery Learning is a learning model that can improve students' scientific literacy. Problem-solving activities in learning activities will have implications for the emergence of curiosity, high attitudes, and sensitivity for students (Astuti et al., 2017). Biology subject is a material subject that has great potential to be implemented using a scientific approach so that students can understand scientific phenomena in everyday life.

One of the Biology materials for the high school level that allows students to learn about scientific phenomena, especially the physiology of the human body, is the circulatory system. The material of the human circulatory was used in this study because students often found misconceptions about the material. Based on several studies that have been conducted, it shows that students have difficulty understanding correctly the sub material of the human circulatory system, namely the structure and function of the circulatory organs and the links between organs so that students are unable to comprehensively explain and understand the main concepts of blood circulation (Chi, 2005; Lee \& Kim, 2014).

The limitation of students' understanding will affect scientific literacy competency, especially in the content dimension. Because the circulatory system material requires a comprehensive understanding from students because the expected competency attainment in the 2013 curriculum demands more than rote ability. Based on this background, the objectives of this study are: 1) developing animated media-based Discovery Learning on circulatory system material, 2) knowing the feasibility of media on circulatory system material, and 3) knowing the effectiveness of the media in increasing the dimensions of scientific literacy content in eleven science class High school. 


\section{METHOD}

This research was conducted using a research and development method with the ADDIE model which consists of five stages, namely: analysis, design, development, implementation, and evaluation. This research focuses on developing animated media-based on Discovery Learning in the circulatory system material. Research and development steps based on the ADDIE model are presented in Figure 1 below:
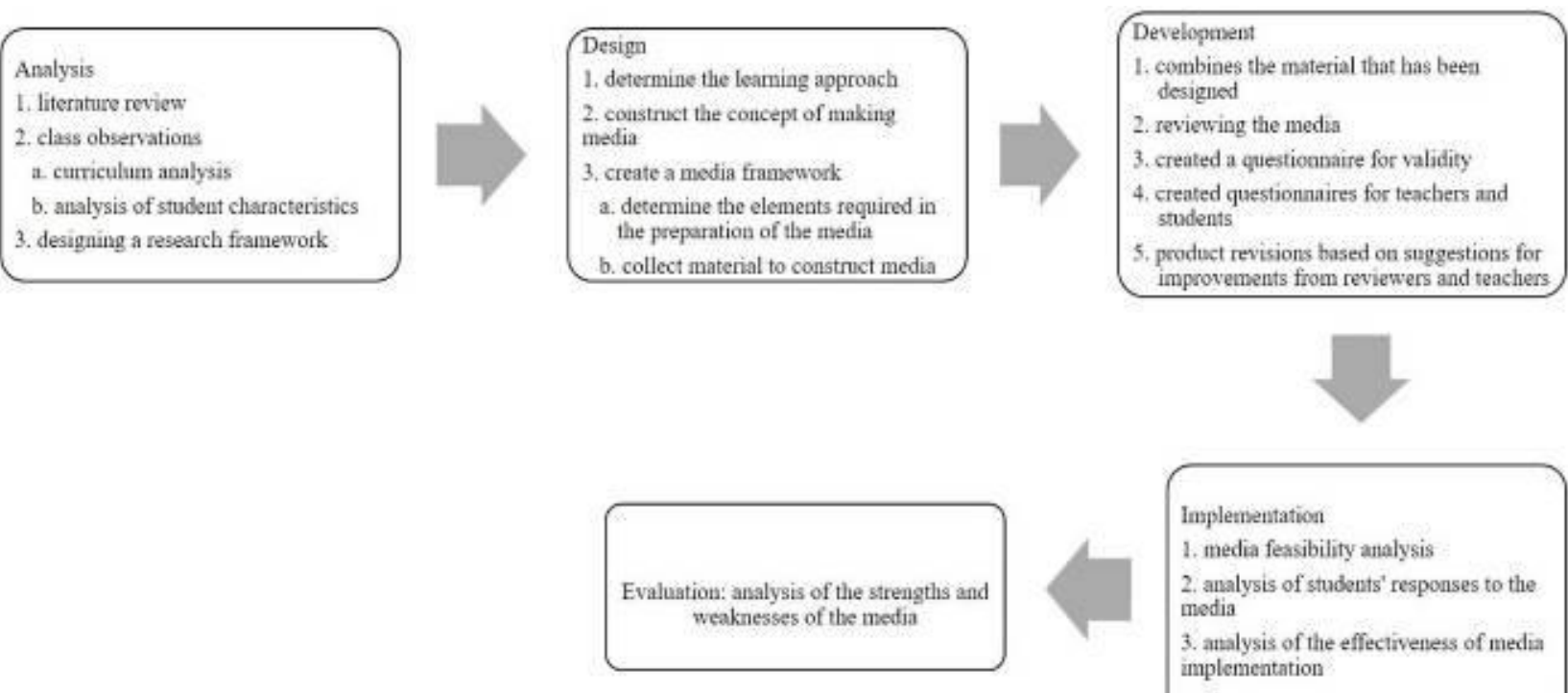

Figure 1. The ADDIE Research and Development Model

The analysis stage was focused on identifying student characteristics and filling out questionnaires. Besides, the biology teacher was also interviewed. Furthermore, the analysis results were carried out by students to determine the level of student understanding of the circulatory system based on learning indicators. The process of curriculum analysis is carried out to determine the achievement of the learning indicators that will be adjusted with the development of animated mediabased Discovery Learning. The design stage is the process of designing a learning media prototype which is carried out by analyzing various references to compile the human circulatory system material. Furthermore, designing the display design of learning media following predetermined indicators and compiling an assessment instrument. The development stage is the validation process of animated media-based Discovery Learning which is directly justified by experts and users (Biology teachers)

The data obtained in this study are qualitative and quantitative. Quantitative data were obtained from the results of correspondence assessments, while qualitative data were obtained from suggestions from respondents. In this study, the data were obtained from media validation, test readability of animated media-based Discovery Learning, media effectiveness, and media improvement on the dimensions of scientific literacy content. Media validation was carried out by two experts, namely media experts and material experts, as well as a biology teacher.

\section{Research Instrument}

The trial subjects used a group of students of class XI IPA 1 Senior High School of Yasiha Gubug with a total of 30 students on September 9, 2019 - November 15, 2019, odd semester of the 2019/2020 school year on the human blood circulation system. Determination of the subject group of students in this study is by purposive sampling. The researcher gave a pretest and posttest for the treatment group through product implementation and gave a post-test to determine the effectiveness of animated media-based Discovery Learning on circulatory system material on the dimensions of scientific literacy content.

The media validation process is carried out using the validation instrument given to each expert. Media expert validator assessment indicators include attractiveness or opening, presentation, and programming (Pemberton dkk., 2005). Aspects used to validate content include 1) aspects of content quality and objectives which include: 2) aspects of learning quality (Wulandari, 2017). The 
results of the assessment from the validator were then analyzed and the level of validity of the media was determined based on the validity criteria of the media. The feasibility level of the media consists of: 1) invalid, 2) less valid (41\% $-60 \%)$, needs a total revision, 3) quite valid, needs a little revision $(61 \%-70 \%), 4)$ valid, does not need to be revised $(71 \%-83 \%), 5)$ very valid, no need for revision $(84 \%-100 \%)$

The research instruments used in this study consisted of 1) validation sheets from media experts, material experts, and high school biology teachers, 2) pretest and posttest question sheets to measure the dimensions of scientific literacy content. Limited trials were carried out using a preexperimental design using one treatment group (Sugiyono, 2016). The trial subjects used a group of students of eleven science class I SMA Yasiha Gubug with a total of 30 students on September 9, 2019 - November 15, 2019, odd semester of the 2019/2020 school year. Determination of the subject group of students in this study is by purposive sampling. The researcher gave a pretest and posttest for the treatment group through product implementation and gave a post-test to determine the effectiveness of animated media-based Discovery Learning on circulatory system material on the dimensions of scientific literacy content.

\section{Research Subject}

Limited trials were carried out using a pre-experimental design using one treatment group (Sugiyono, 2016). The trial subjects used a group of students of eleven science class I Senior High School of Yasiha Gubug with a total of 30 students on September 9, 2019 - November 15, 2019, odd semester of the 2019/2020 school year on the human blood circulation system. Determination of the subject group of students in this study is by purposive sampling. The researcher gave a pretest and posttest for the treatment group through product implementation and gave a post-test to determine the effectiveness of animated media-based Discovery Learning circulatory system material on the dimensions of scientific literacy content.

\section{Data Analysis}

Determination of the effectiveness of animated media-based Discovery Learning in increasing scientific literacy content was carried out by paired sample t-test with hypothesis testing, namely: a) Ho: animated media based Discovery Learning on human circulatory system material was not effective against the dimensions of scientific literacy content, b) Ha: animated media-based Discovery Learning on human circulatory system material is not effective on the dimensions of scientific literacy content. The instrument for measuring the dimensions of literacy content is a test instrument based on seven indicators based on the scientific literacy test from C Gormally, dkk (2012). The following is an indicator of the dimensions of scientific literacy content in Table $1 .$.

Table 1. Indicators for Science Literacy Content

\begin{tabular}{|c|c|}
\hline Kriteria & Indikator \\
\hline \multirow{3}{*}{$\begin{array}{l}\text { Understand the } \\
\text { Discovery Learning } \\
\text { method that leads to } \\
\text { scientific knowledge }\end{array}$} & $\begin{array}{l}\text { 1. Able to conclude problems based on data analysis and interpretation ( } 3 \\
\text { (essay), } 1 \text { and } 2 \text { (multiple choice) }\end{array}$ \\
\hline & 2. Able to make graphs / diagrams to represent data. (4 and 5 (essay)) \\
\hline & 3. Evaluating scientific information effectively $(3,8,9$ (multiple choice)) \\
\hline \multirow{4}{*}{$\begin{array}{l}\text { Construct, analyze, } \\
\text { and interpret } \\
\text { scientific data and } \\
\text { information }\end{array}$} & 4. Identifying scientific arguments validly $(6,7,10$ (multiple choice) $)$ \\
\hline & $\begin{array}{l}\text { 5. Able to present scientific phenomena through logical understanding, simple } \\
\text { experimental steps, and apply scientific concepts ( } 1 \text { (essay)) }\end{array}$ \\
\hline & 6. Solving problems through scientific skills (2 (essay)) \\
\hline & $\begin{array}{l}\text { 7. Able to read and interpret data through writing, tables, graphics, and verbal } \\
\text { communication }(4,5 \text { (multiple choice) })\end{array}$ \\
\hline
\end{tabular}

The data obtained from the literacy content dimension test instrument were analyzed using the $\mathrm{N}$-gain test which aims to calculate the increase based on the $\mathrm{N}$-gain score category (Hake, 2002). (Hake, 2002). The $\mathrm{N}$-gain assessment indicators are presented in Table 2 below 
Table 2. Category N-gain score

\begin{tabular}{cc}
\hline N-Gain value & Category \\
\hline $\mathrm{g}>0,7$ & High \\
\hline $0,3 \leq \mathrm{g} \leq 0,7$ & Medium \\
\hline $\mathrm{g}<0,3$ & Low \\
\hline
\end{tabular}

\section{RESULTS AND DISCUSSION}

Based on the data obtained, animated media based on Discovery Learning have been developed using the ADDIE model and are declared feasible to be implemented in learning, especially to increase the dimensions of scientific literacy content. So in this section, we will discuss the process and results of the development of learning media for animated media-based Discovery Learning, the acquisition of the feasibility level of animated media-based Discovery Learning, and the effectiveness of animated media based on Discovery Learning, and increasing the dimensions of scientific literacy content through learning animated media-based Discovery Learning.

\section{Analysis Stage}

The analysis stage is an activity to obtain relevant information related to the needs of learning media which consists of analyzing the needs and characteristics of students, analyzing concepts and materials, analyzing the results of assignments carried out by students, determining learning outcomes based on the 2013 curriculum to teachers and senior high school students. The interview was conducted in an open-ended type which aims to obtain information about problems, especially in the material of the human circulatory system. Based on the results of interviews with two Biology teachers at Senior High School of Yasiha Gubug, they only used some of the media available in schools, namely props. However, the media on the circulatory system still does not exist so that the teacher only teaches the circulatory system material using the lecture method.

Based on the results of the students' responses to the questionnaire, it was found that it was difficult to understand the concept of blood, the structure, and function of the circulatory system organs, and their implications in everyday life. The lack of media availability that leads to the type of multimedia causes students to indirectly experience difficulty understanding abstract concepts. So we need a special media that can specifically encourage student understanding through the use of technology-based media (multimedia) so that they can improve their learning outcomes, especially the dimensions of scientific literacy content.

\section{Design Stage}

The design stage is a media design process that takes into account the attractiveness or opening, presentation, and programming (Pemberton et al., 2005). The initial design was carried out by designing images and writing in the form of a storyboard for the human blood circulation system. The prototype in the form of a storyboard will then become the basis for the design using Adobe Flash 11 software which consists of the main menu, namely an introduction (basic competencies and learning indicators), materials (blood type and blood transfusion, heart structure, and function, structure, and function of blood vessels).

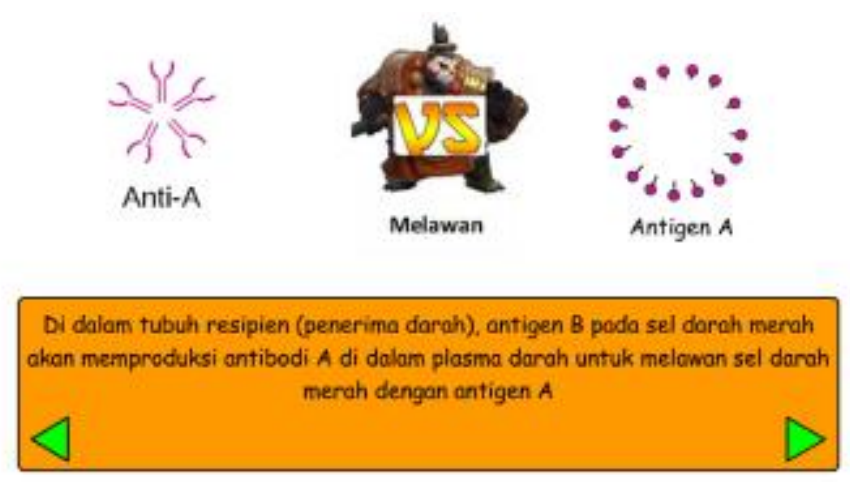

Figure 2. Display of the stimulus phase to students 
Based on Figure 2, it is the initial explanation given to students regarding the concept of antigen, antibody, and the function between each blood component. Students have explained the main concepts related to blood. Furthermore, students are also asked to read book references that they have and make questions related to concepts they have not yet understood.

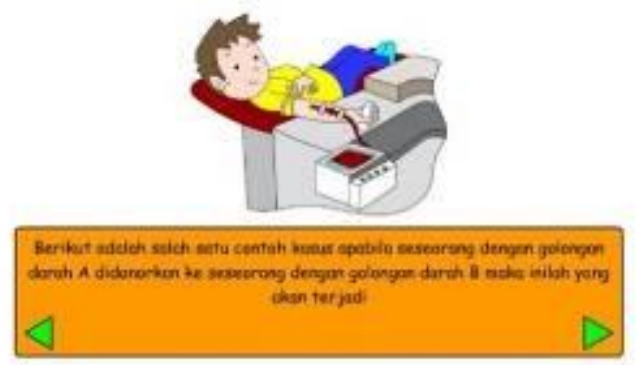

(a)

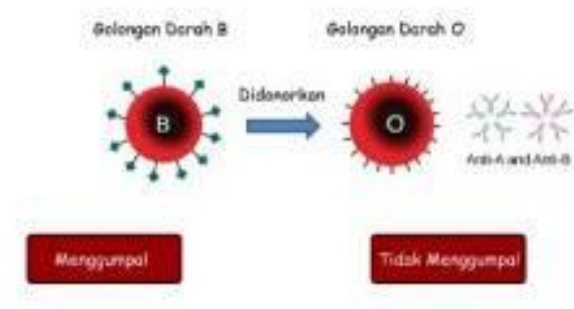

(b)

Figure 3. Display content at the problem identification stage

Figure 3. is a display of content that allows students to identify problems. Students identify cases related to the blood transfusion process. Then the students were asked to formulate their respective hypotheses related to the blood transfusion process associated with blood clotting.

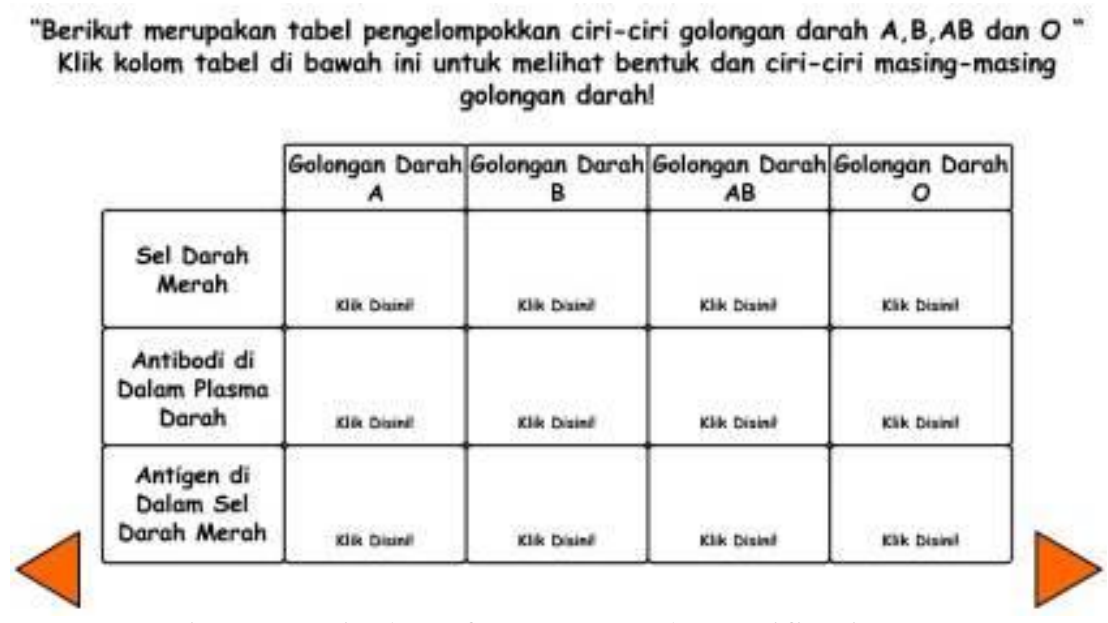

Figure 4. Display of contents at the Verification Stage

Figure 4. shows student activities to complete the table based on the verification process that has been carried out. The concept of filling in tables is the result of collecting information by students to find relevant answers. At this stage, students prove the hypotheses that have been previously made. Students provide relevant answers related to the blood transfusion process that has been previously given in the problem identification phase. After verification, students will draw conclusions that apply to the problem being solved. The process of concluding becomes the basis for generalizing the same case.

\section{Development Stage}

The development stage is the process of evaluating the animation media product based on Discovery Learning on the circulatory system material from the validation of material experts, media experts, and users (high school biology teachers). The following is a description of the validation results of the animated media-based Discovery Learning:

Validation result of animated media-based Discovery Learning

Based on the validation results from material experts, media experts, and teachers, it was found that animated media-based Discovery Learning was concluded to be valid with a few revisions 
so that the media was feasible to be implemented in learning. The following is the data from the validation test conducted by material experts.

Table 3. Validation Results of Discovery Learning-based Animated Media by Material Experts

\begin{tabular}{lcc}
\multicolumn{1}{c}{ Aspects that are validated } & $\begin{array}{c}\text { Percentage } \\
(\%)\end{array}$ & Criteria \\
\hline $\begin{array}{l}\text { The suitability of the material with the specified } \\
\text { competencies }\end{array}$ & 83,3 & Valid \\
\hline Accuracy and correctness of the material & 81,25 & Valid \\
\hline Learning support material & 85 & Valid \\
\hline Average & 83,19 & Valid \\
\hline
\end{tabular}

Table 3 shows that the material expert validator provides an assessment of animated mediabased Discovery Learning on each indicator, namely: the suitability of the material with the competency score of $83.33 \%$ (valid), the accuracy and truth of the material score $81.25 \%$ (valid), the material supporting the lesson score $85 \%$ (valid). Based on the mean of each indicator, it is concluded that the media is suitable for use in learning with category outcomes, namely valid with revision. Material validation is important because it contributes to media development and constructs material validly. Besides, validation also plays a role in avoiding misconceptions that often occur from students, especially in the use of animation media (Safrida et al., 2017).

Based on the validation results of Discovery Learning-based animated media conducted by media experts, the learning media is said to be valid with a few revisions so that the media is feasible to be implemented in the classroom. The following shows the data from the results of the validation test conducted by media experts in Table 4 .

Table 4. The results of the media validation animated media-based Discovery Learning by Media Experts

\begin{tabular}{lcc}
\hline Aspects that are validated & Percentage (\%) & Criteria \\
\hline Attractiveness & 80 & Valid \\
\hline Serving eligibility & 83,33 & Valid \\
\hline Programming & 85 & Valid \\
\hline Average & $82,77 \%$ & Valid \\
\hline
\end{tabular}

Based on Table 4, it can be seen that the percentage of the attractiveness aspect was obtained $80 \%$ with valid criteria, the presentation feasibility aspect was obtained $83.33 \%$ with valid criteria, the programming aspect was obtained $85 \%$. From these three aspects, the average was $82.77 \%$ with valid criteria and a little revision. Based on these mean values, it can be concluded that Adobe flash is suitable for use in biology learning, especially in the human circulatory system material.

Table 5. The results of the animation media validation by the teacher

\begin{tabular}{lcc}
\hline \multicolumn{1}{c}{ Indicator } & Percentage (\%) & Category \\
\hline Layout & 97 & Valid \\
\hline Language & 95 & Valid \\
\hline Content & 98 & Valid \\
\hline Contribution & 100 & Valid \\
\hline Product excellence & 80 & Valid \\
\hline \multicolumn{1}{c}{ Average } & $94 \%$ & Valid \\
\hline
\end{tabular}

Table 5 is the teacher's assessment of the animated media-based Discovery Learning, media on the material of the human circulatory system. Based on the assessment given by the Biology teacher, the media was declared valid without having to go through a revision process. However, some suggestions are given by material and media experts, so the media will undergo a process of improvement following the suggestions given.

\section{Implementation Stage}


The implementation stage is the process of testing Discovery Learning-based animated media which is limited to one group of students. Testing in this stage will analyze the effectiveness of the product in increasing the dimensions of scientific literacy content. The following is a description of the implementation of the animated media-based Discovery Learning.

Limited trial of Discovery Learning-based animated media on the material of the human circulatory system

The implementation of animated media-based Discovery Learning on the material of the human circulatory system was carried out in a limited manner by using one class with a total of 30 students. At the first meeting, students were given a preliminary test to determine the initial ability of the dimensions of scientific literacy content, which was then carried out by the application of animated media-based Discovery Learning to the human circulatory system material for 4 meetings (4 meetings x 90 minutes/meeting). At the fourth meeting, students were given a posttest to determine the increase in the dimensions of scientific literacy content. This limited trial was conducted to determine the effectiveness of the media on the dimensions of scientific literacy content. A summary of the normality and homogeneity tests as a prerequisite test is presented in Table 6.

Table 6. Normality and Homogeneity Test

\begin{tabular}{|c|c|c|c|c|c|}
\hline \multirow{2}{*}{ Type of test } & \multicolumn{3}{|c|}{ Kolmogorov-Smirnov } & \multirow{2}{*}{$\alpha$} & \multirow{2}{*}{ Conclusion } \\
\hline & Variable & df & Sig. & & \\
\hline Normality & Scientific literacy content & 25 & 0,142 & 0,05 & Normally distributed \\
\hline Type of test & Levene test & df & Sig. & $\alpha$ & Conclusion \\
\hline Homogeneity & Scientific literacy content & 25 & 0,110 & 0,05 & Homogeneous Data \\
\hline
\end{tabular}

Based on the results obtained in Table 6. The normality test using the Kolmogorov-Smirnov criteria obtained results of $0.057>0.05$, which means the distribution of data on the dimensions of scientific literacy content in a population is normally distributed. The results of the homogeneity test using the provisions of the Levene test show that the value of $0.110>0.05$, which means that the pretest and posttest data in the sample group have a level of diversity that is not much different from one another so that the data in the student group is homogeneous.

Based on the results of the prerequisite test on the normality and homogeneity test, it shows that the dimensional data of scientific literacy content has met the requirements for inferential statistical tests. The test used in making decisions on the effectiveness of animated media-based Discovery Learning is the paired sample t-test. The results of the paired sample t-test calculation results can be presented in Table 7.

Table 7. Paired Sample t-test

\begin{tabular}{clcccc}
\hline Test type & \multicolumn{1}{c}{ Variable } & df & Sig (2-tailed) & $\alpha$ & Conclusion \\
\hline Paired Sample t-test & $\begin{array}{l}\text { Dimensions of scientific literacy } \\
\text { content }\end{array}$ & 24 & 0,000 & 0,05 & Ho was rejected \\
\hline
\end{tabular}

In Table 7, the analysis results obtained from the paired-samples t-test of $0.00<0.05$, which means that Ho is rejected. The rejection of Ho means that the animated media-based Discovery Learning on the human circulatory system material is effectively used in the dimensions of scientific literacy content. The analysis of the increase in the dimensions of scientific literacy content as a whole is calculated based on the acquisition of students' learning outcomes (pretest and posttest). There was an increase in the dimensions of scientific literacy content through the implementation of animated media-based Discovery Learning which was analyzed using the N-gain category. A summary of the increase in the dimensions of scientific literacy content based on the $\mathrm{N}$-gain is presented in Table 8. 
Table 8. N-Gain Test

\begin{tabular}{lc}
\hline Category & Percentage (\%) \\
\hline High & $0 \%$ \\
\hline Medium & $76 \%$ \\
\hline Low & $24 \%$ \\
\hline Mean N-Gain & $52 \%$ \\
\hline
\end{tabular}

Based on the results of the calculation of the N-Gain test in Table 8 , it shows that there are no students who have an increase in the high category, as many as $76 \%$ of students have an increase in the medium category and $24 \%$ of students have an increase in the low category. The average N-Gain with a gain of $52 \%$ can be concluded that the increase in the ability of the dimensions of students' science literacy content is in the medium category.

This was because the animated media-based Discovery Learning used could be facilitated students in carrying out learning activities with Discovery Learning steps contained in student activity sheets so that students could be stimulated in term of creativity through demonstrations activity based on the information they get from animated media (Sugandi \& Rasyid, 2019). In addition to viewing text, pictures, and animated videos, students can also process this information through group activities. Dewi et al., (2017) explained that Discovery Learning is a learning model that can facilitate students in understanding scientific information.

The process of empowering students' scientific literacy skills requires each individual to be able to understand, communicate and apply science in the process of problem problems. This process also proves that the animated media-based Discovery Learning on human blood circulation material has a significant role and benefits for students in the learning process because it can make it easier for students to understand a concept so that students 'conceptual mastery system increases, students' scientific literacy also increases (Rosandi et al., 2019).

\section{Improved Dimensions of Science Literacy Content}

The implementation of animated media-based Discovery Learning on human circulatory system material shows an increase in the dimensions of scientific literacy content based on the results of the pretest and posttest. The following is a presentation of increasing the dimensions of student science literacy content in Figure 5.

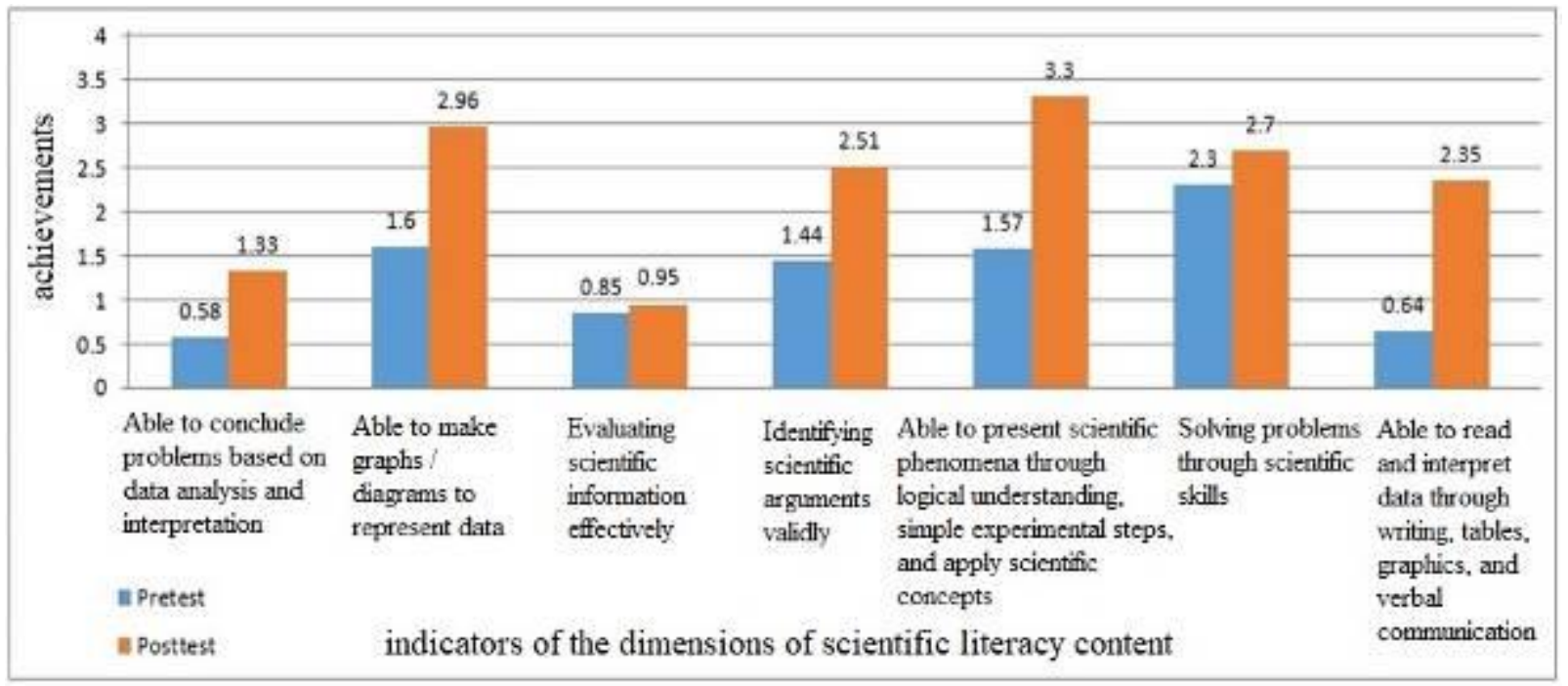

Figure 5. Improved dimensions of students' scientific literacy content based on the pretest and posttest

Comparison of results among all indicators, there was an increase in the indicators presenting scientific phenomena through students' logical understanding of 1.73. Presentation of scientific phenomena through learning activities is related to the transfusion system. The illustration process about the case problem of blood transfusion is given through animated media-based Discovery Learning-based. The learning process provides scientific issues as an effort to stimulate students' 

results of the research explained that the integration process of scientific social issues can provide a stimulus to increase students' scientific literacy.

The result based on the indicator of interpreting data through writing, tables, graphics, and verbal communication, the score increased significantly, namely 1.71 . The process of interpreting data in learning activities is given by providing a table for grouping the characteristics of blood groups found in adobe flash based on Discovery Learning. Presentation of the table as a form of visualization of the characteristics of blood groups is an effort to make it easier for students to understand and answer questions related to erythrocyte antigen-antibody compatibility. Interpretation of data based on direct observation has helped students understand how to interpret information in various data presentations. This finding is also supported by the research of Nofiana \& Julianto (2018) stated that students could more easily understand concepts about literacy content when observing objects contextually.

Figure 5. also shows that the indicator evaluating scientific information did not experience a significant increase in score, namely 0.1 . The activity of evaluating information sources is carried out through a process of student confirmation of the relevance of the information obtained for problemsolving. The difficulties experienced by students' information when they faced process information in the form of scientific questions. Some students also had confused about scientific questions used for investigative activities. The difficulty of students in processing information is due to factors in the mastery of problem-solving. Processing information is part of declarative knowledge that requires mastery of the problems to be resolved (Pebriana, Kamid, \& Hariyadi, 2019).

The findings in this study also saw an indirect relationship between indicators of evaluation of information sources and students' ways of solving problems. Based on the data in Figure 5, the low increase in students' ability to evaluate information also causes the achievement of problem-solving indicators through the scientific approach to not experience an optimal increase (score 0.4). Based on data, the way students ensure data reliability, think objectively and make explanations for generalizations have an impact on the process of solving problems scientifically. According to Sunarti, (2015) in their research, students also experienced the same problem, namely the limited ability to investigate questions to the process of evaluating scientific questions which had an impact on students' low ability to solve problems.

In the context of this research, it was also found that the ability to argue scientifically and to think logically has increased. However, the teacher's follow-up in the future is necessary to familiarize students with learning patterns that lead to higher-order thinking. Because improvements to indicators of the ability to evaluate information and solve problems scientifically require a learning process that leads to higher-order thinking skills. Gustina (2015) found that the profile of scientific literacy on biology content and high-level thinking skills of high school students both reached the low category. This reinforces the findings of this study that the achievement of the dimensions of scientific literacy content in Biology learning can also be supported by the high level of thinking that students have individually.

\section{CONCLUSION}

Based on the research and development that has been carried out in developing animated-media based Discovery Learning on human circulatory system material to increase the dimensions of scientific literacy content, it is concluded: 1) Animated media based on Discovery Learning is suitable for use in learning, especially on human circulatory system material for class eleven science class senior high school, 2) Animated media-based the Discovery Learning learning model is effective in increasing the dimensions of students' scientific literacy content based on the paired sample t-test with sig. 2 tailed $(0.000)<0.053)$ Animated media based on the Discovery Learning model can increase the dimensions of students' scientific literacy content by $52 \%$ with sufficient category.

\section{REFERENCES}

Ahluwalia, M. S. (2016). Peningkatan Kemampuan Literasi dan Disposisi matematis siswa SMP melalui model pembelajaran discovery learning. In IOSR Journal of Economics and Finance (Vol. 3). https://doi.org/https://doi.org/10.3929/ethz-b-000238666

Arfiyanto, R., \& Pusporini, W. (2017). Meningkatkan Kreativitas dan Hasil Belajar IPA Siswa Kelas 
Jurnal Pendidikan Sains (JPS). Vol. 9(1) pp 69-80 ISSN:2339-0786

DOI: https://doi.org/10.26714/jps.9.1.2021.69-80

VIII MTs. YAPP Jetis Saptosari Gunugkidul Melalui Penggunaan Media Alat Peraga IPA. Jurnal Ilmiah Pendidikan Ipa, 4(1), 1576-1580.

Arohman, M., Saefudin, \& Priyandoko, D. (2016). Kemampuan Literasi Sains Siswa pada Pembelajaran Ekosistem. Proceeding Biology Education Conference, 13(1), 90-92.

Astuti, R., Sujana, S., \& Hafinah, N. (2017). Pembelajaran Berbasis Masalah Untuk Meningkatkan Literasi Sains Pada Materi Hubungan Makanan Dengan Kesehatan. Jurnal Pena Ilmiah, 2(1), 261-270. https://doi.org/10.17509/jpi.v2i1.10661

Asyhari, A. (2015). Profil Peningkatan Kemampuan Literasi Sains Siswa melalui Pembelajaran Saintifik. Jurnal Ilmiah Pendidikan Fisika Al-Biruni, 4(2), 179. https://doi.org/10.24042/jpifalbiruni.v4i2.91

Chi, M. T. H. (2005). Commonsense conceptions of emergent processes: Why Some Misconceptions are Robust. Journal of the Learning Sciences, 14(2), 161-199. https://doi.org/10.1207/s15327809j1s1402_1

Dewi, S. R., Nurmilawati, M., \& Budiretnani, D. A. (2017). Improving of Scientific Literacy Ability using Discovery Learning Model at the seventh Grade Students of State JHS 3 Ngronggot, Nganjuk-Indonesia. Jurnal Pendidikan Biologi Indonesia, 3(3), 266. https://doi.org/10.22219/jpbi.v3i3.4597

Gormally, C., Brickman, P., \& Lutz, M. (2012). Developing a Test of Scientific Literacy Skills (TOSLS): Measuring Undergraduates' Evaluation of Scientific Information and Arguments. Life Sciences Education, 11, 364-377.

Gustina, A. (2015). Analisis Kemampuan Literasi Sains Dan Kemampuan Berpikir Tingkat Tinggi Siswa SMA Kelas X di Kota Solok Pada Konten Biologi. Universitas Pendidikan Indonesia.

Hake, R. (2002). Relationship of Individual Student Normalized Learn Gains in Mechanics with Gender, High-School Physics, and Pretest Scores on Mathematics and Spatial Visualization.

Ilahi, M. T. (2012). Pembelajaran discovery Strategy \& Mental Vocational Skill / Mohammad Takdir Ilah. Yogyakarta: Yogyakarta: Diva Press.

Khasanah, N., \& Dwiastuti, S. (2016). Pengaruh Model Guided Discovery Learning Terhadap Literasi Sains ditinjau dari Kecerdasan Naturalis. Proceeding Biology Education Conference, 13(1), 346351.

Lee, S., \& Kim, H. B. (2014). Exploring Secondary Students' Epistemological Features Depending on the Evaluation Levels of the Group Model on Blood Circulation. Science and Education, 23(5), 1075-1099. https://doi.org/10.1007/s11191-013-9639-9

Nofiana, M., \& Julianto, T. (2018). Upaya Peningkatan Literasi Sains Siswa Melalui Pembelajaran Berbasis Keunggulan Lokal. Biosfer : Jurnal Tadris Biologi, 9(1), 24. https://doi.org/10.24042/biosf.v9i1.2876

Nurhayati, N. (2018). Peningkatan Kemampuan Literasi Sains dan Hasil Belajar Siswa Pada Pokok Bahasan Lingkungan dengan Menerapkan Pembelajaran Discovery Learning di Kelas VII SMP Negeri 2 Binjai. Jurnal Pelita Pendidikan, 6(4). https://doi.org/10.24114/jpp.v6i4.11694

OECD. (2019). PISA 2018 Results. In OECD Publishing.

Pebriana, Kamid, \& Hariyadi, B. (2019). Proses Berpikir Ilmiah Siswa Tipe Climber Dalam Pemecahan Masalah Biologi Di SMA. Edu-Sains, 8(2), 33-41. Retrieved from http://repositorio.unan.edu.ni/2986/1/5624.pdf

Pemberton, L., Fallahkhair, S., Schools, \& Masthoff, J. (2005). Learner Centred Development of a Mobile and iTV Language Learning Support System. Journal Educational Technology \& Society, 8(4), 52-63.

Rosandi, A. K. F., Tjandrakirana, T., \& Supardi, I. (2019). Pengembangan Multimedia IPA Berbasis Flash untuk Meningkatkan Literasi Sains Siswa SMP. Prisma Sains : Jurnal Pengkajian Ilmu Dan Pembelajaran Matematika Dan IPA IKIP Mataram, 4(1), 34. https://doi.org/10.33394/jps.v4i1.1138

Rusniati, R. (2016). Pendidikan Nasional dan Tantangan Globalisasi. Jurnal Ilmiah Didaktika, 16(1), 105. https://doi.org/10.22373/jid.v16i1.589

Safrida, S., Cut, R. ., \& Abdullah, A. (2017). Pengunaan Modul dan Media Animasi dalam mengurangi Miskonsepsi Siswa pada Materi Sistem Peredaran Darah di SMAN 5 Kota Banda Aceh. Jurnal Pencerahan, 11(1), 39-45.

Sudarmin. (2015). Model Pembelajaran Inovatif Kreatif (Model PAIKEM dalam Konteks Pembelajaran dan Penelitian Sains Bermuatan Karakter) (Parmin, Ed.). Semarang: Swadaya

https://jurnal.unimus.ac.id/index.php/JPKIMIA/index 
Jurnal Pendidikan Sains (JPS). Vol. 9(1) pp 69-80 ISSN:2339-0786

DOI: https://doi.org/10.26714/jps.9.1.2021.69-80

Manunggal.

Sugandi, M. K., \& Rasyid, A. (2019). Pengembangan Multimedia Adobe Flash Pembelajaran Biologi Melalui Project Based Learning Untuk Meningkatkan Kreativitas Siswa Pada Konsep Ekosistem. Biodik: Jurnal Ilmiah Pendidikan Biologi, 5(3), 181-196.

Sugiyono. (2016). Metode Penelitian Kuantitatif Kualitataif dan Kombinasi (Mixed Methods). Journal of Chemical Information and Modeling, 53(9), 240. https://doi.org/10.1017/CBO9781107415324.004

Sunarti, T. (2015). Pemahaman Literasi Sains Mahasiswa Calon Guru Fisika Universitas Negeri Surabaya. Seminar Nasional Fisika Dan Pembelajarannya 2015, 34-39.

Suprapto. (2006). Peningkatan Kualitas Pendidikan Melalui Media Pembelajaran Menggunakan Teknologi Informasi Di Sekolah. Jurnal Ekonomi \& Pendidikan, 3(1), 42-52.

Tohir, M. (2019). Hasil PISA Indonesia Tahun 2018. Paper of Matematohir, 2(1), 1-2.

Ulfa, U., Saptaningrum, E., \& Kurniawan, A. F. (2017). Pengaruh Model Discovery Learning Pada Mata Pelajaran IPA Terpadu Terhadap Penguasaan Literasi Sains Siswa. Prosiding SNFA (Seminar Nasional Fisika Dan Aplikasinya), 2, 257. https://doi.org/10.20961/prosidingsnfa.v2i0.16408

Wulandari, Y. (2017). Kelayakan Aspek Materi Dan Media Dalam Pengembangan Buku Ajar Sastra Lama. Gramatika S, 3(2), 162-172. https://doi.org/10.22202/jg.2017.v3i2.2049

Yaumi, Wisanti, \& Admoko, S. (2017). Penerapan Perangkat Model Discovery Learning pada Materi Pemanasan Global untuk Melatihkan Kemampuan Literasi Sains Siswa SMP Kelas VII. EJournal Pensa, 5(1), 38-45. 